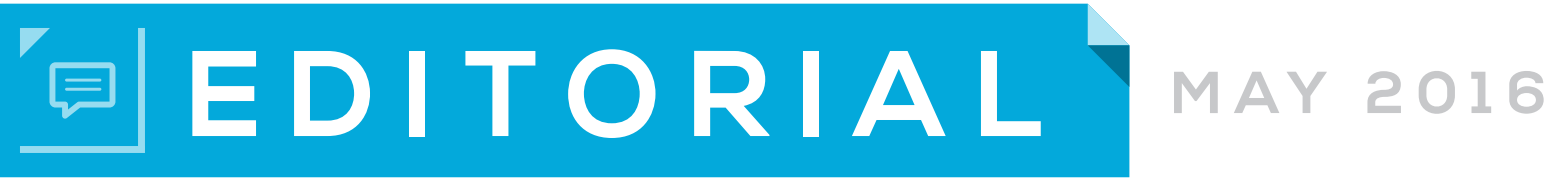

\title{
Journal of Intellectual Freedom and Privacy
}

An Expanded Opportunity for Discourse on Intellectual Freedom and Privacy
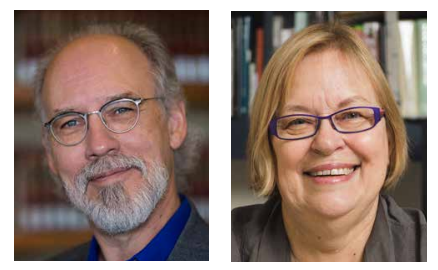

James LaRue, Director, ALA Office for Intellectual Freedom and Executive Director of the Freedom to Read Foundation.

Barbara Jones, Former Director, OIF and FTRF, and Guest Editor of Journal of Intellectual Freedom and Privacy, vol. 1, no. 1.

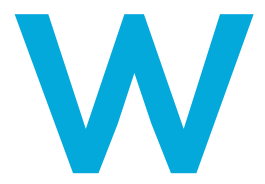

e are so pleased to introduce the first issue of the Journal of Intellectual Freedom and Privacy (JIFP).

JIFP is an expansion of The Newsletter on Intellectual Freedom (NIF), published between 1952 and 2015. Ever mindful of serials librarians' woes, we hereby state that this new publication is a continuation of NIF, but begun over with vol. 1, no. 1. The publication will be online only. For questions on subscriptions, contact Deborah Caldwell-Stone, deputy director of the Office for Intellectual Freedom, at dstone@ala.org.

For the past few years, we have watched the term, "intellectual freedom," expand into many disciplines and areas of library practice. We have also noted the dramatic rise of focus on privacy in the life of libraries and policy. Finally, we want to encourage librarians and scholars to specialize in the fields of intellectual freedom and privacy. We hope that this journal will grow in content, coverage, and complexity, based on readers' input and needs. For example, we would welcome suggestions for issue no. 2 . We are totally open to peer reviewed articles, thus fulfilling a need for those scholars needing to publish for promotion and tenure. We also welcome

PP

\section{WE HOPE THAT THIS JOURNAL WILL GROW IN CONTENT, COVERAGE, AND COMPLEXITY, BASED ON READERS' INPUT AND NEEDS.}

opinion pieces, book reviews, and news or accounts from conferences. We welcome those who want to venture beyond the traditional topics of intellectual freedom, which have often focused on the law. For instance, what is the status of "academic freedom" in today's universities? What does the adoption of anti-bullying policies in high schools tell our youth about the limits of speech? How does Islamophobia show up at the public library? Do the comments on popular news sites signal a robust democratic exchange, or a coarsening of public dialog with its own consequences? At the same time, we promise to continue to include legal news and cases from around the country. To date, NIF and now JIFP are the only publications covering this territory on behalf of libraries and their supporters. 


\section{MARCH 2016 _ EDITORIAL}

This issue begins with the cover history of a banned book, Oil! By Upton Sinclair. We welcome readers to contribute similar histories of reading materials old and new.

There is an extensive analysis of Common Core, contributed by Loretta Gaffney, adjunct professor and postdoctoral fellow at the Department of Information Studies at the University of California, Los Angeles. The topic of Common Core reflects our hope that this new journal will cover issues not always associated with intellectual freedom. Gaffney examines how the Common Core adoption by US schools has affected the intellectual freedom of faculty, students, parents, and administrators. We hope that you will respond to Professor Gaffney's article and we will publish responses in issue no. 2 .
Book reviews are back! We urge readers to contact Deborah Caldwell-Stone at OIF if you are interested in being a reviewer. We will happily provide you with review copies.

Rory Litwin's essay reminds us that intellectual freedom is deeply affected by the structure and economic health of the publishing industry. We hope that you will read it and be prompted to contribute your own thoughts.

And finally, we are pleased to present the "News" section, which comprises the best of NIF and valuable content on legal cases and news. This is at the urging of current subscribers, and we thank Hank Reichman for compiling it.

And at this point, we want to thank Hank Reichman, professor of history emeritus at California State University at Long Beach, for being the editor of this publication for more than thirty years. Hank will continue to compile the news section.

Also, thank you to the volunteer editorial board: Martin Garnar, Rosanne Cordell, Mack Freeman, Clem Guthro, and Mike Wright. Your willingness to work on the transition from NIF to JIFP is deeply appreciated by this guest editor.

Jamie would also like to thank Barbara not only for her good work as his predecessor, but for the labor of love that is the Journal of Intellectual Freedom and Privacy. Advocacy for intellectual freedom in this century may look a little different than it has in the past. May our new publication signal a rebirth of commitment and passionate engagement.

Best wishes, and enjoy!

Barbara and Jamie

\section{Call for Submissions}

The Journal of Intellectual Freedom and Privacy seeks submissions related to intellectual freedom and privacy, both in libraries and in the wider world. Submissions can include:

- research articles (peer review upon request)

- articles and essays discussing or describing policies, practices, projects, legal issues, and scholarly activities about or related to intellectual freedom, privacy, and professional ethics

- personal accounts of censorship and intellectual freedom challenges

- opinion pieces and essays on current and topical intellectual freedom and privacy issues

- book and publication reviews

The Journal of Intellectual Freedom and Privacy encourages publishers and authors to submit books and other materials for review.

Please send all inquiries, submissions, and review copies to Deborah Caldwell-Stone, Office for Intellectual Freedom, American Library Association, 50 East Huron Street, Chicago, Illinois, 6061l. Items may also be sent electronically to dstone@ala.org. 